\title{
Implementering af MARPOL Annex VI i nordiske småsamfund
}

Frank Stuer-Lauridsen and Kristina Kern-Nielsen 
For:

August

Nordisk Ministerråd

2017

Dokument type:

Arbejdspapir

\section{Implementering af MARPOL}

\section{Annex VI i nordiske}

\section{småsamfund}




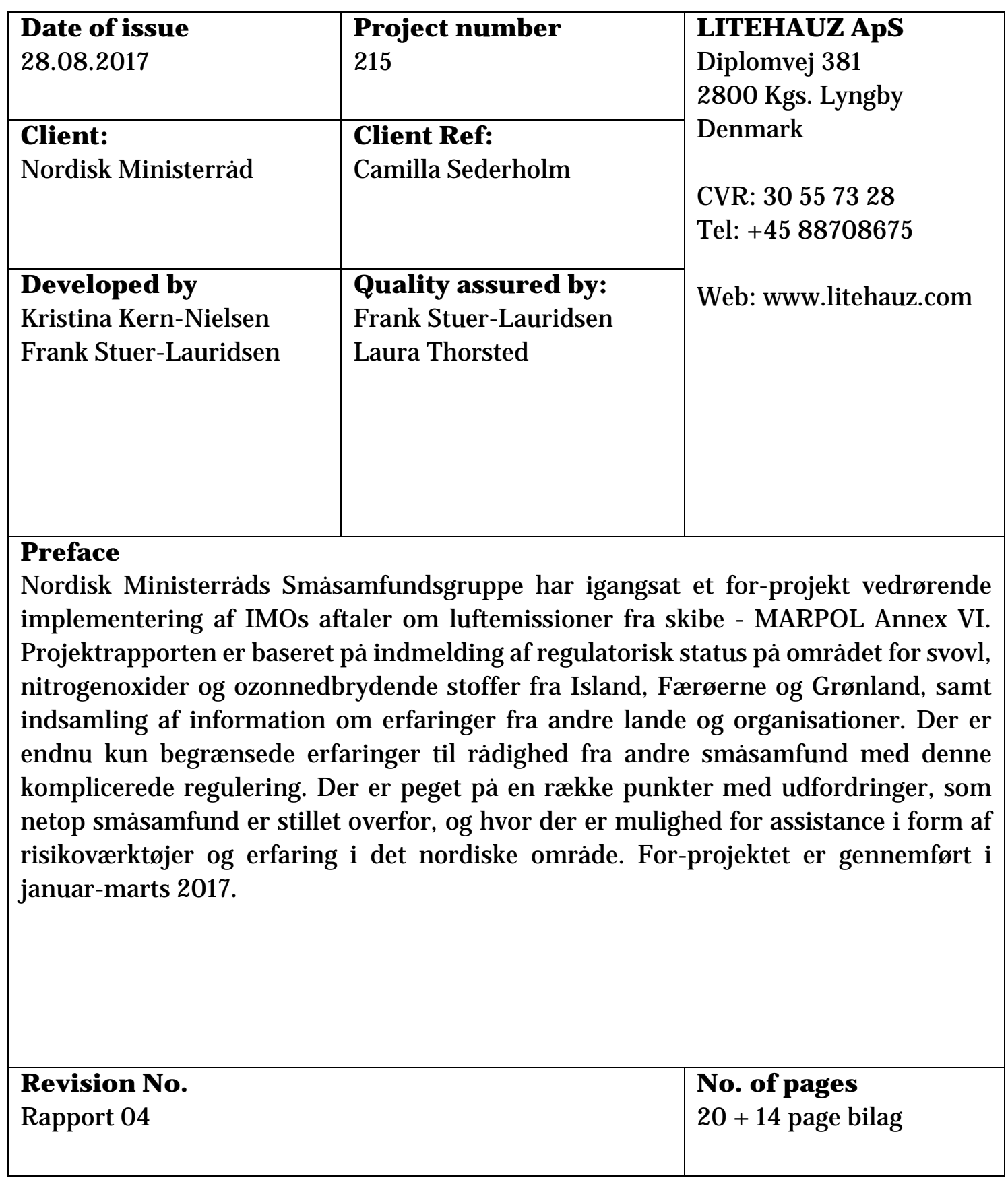




\section{Indhold}

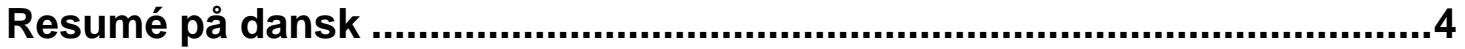

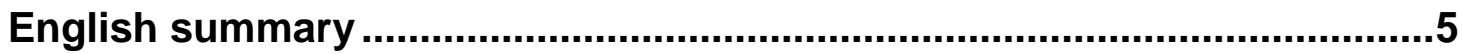

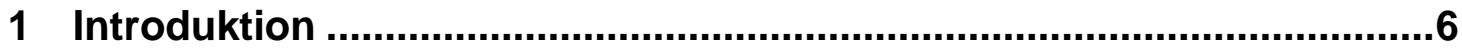

2 Beskrivelse af MARPOL Annex VI og implementering i EU/EØS ..........7

2.1 Oversigt over MARPOL Annex VI reglernes indhold .................................

2.2 Reglerne om ODS, nitrogenoxider og svovl ............................................

2.3 Implementering af MARPOL Annex Vl i EU/EØS ......................................

3 Implementering i Island, Færøerne og Grønland .................................10

4 Beskrivelse af hvordan regler simplest overholdes............................13

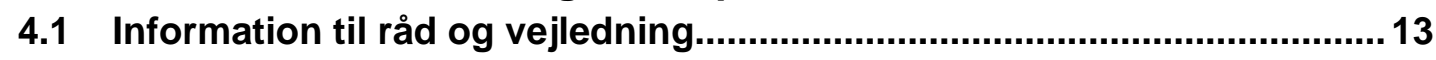

4.2 Andre småsamfund ...........................................................................14

4.3 Indsats på inspektion, certificering og kontrol ......................................14

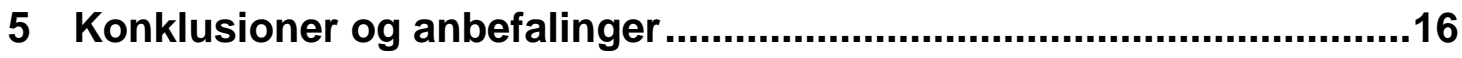

5.1 Overordnet konklusioner.......................................................................

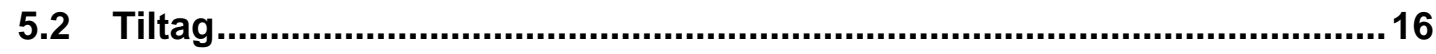

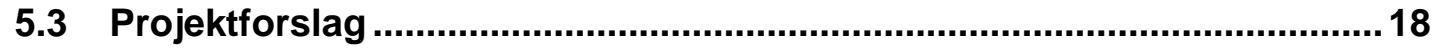

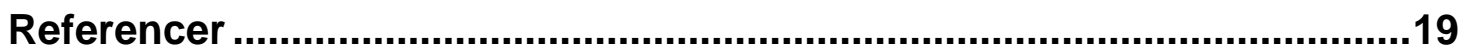

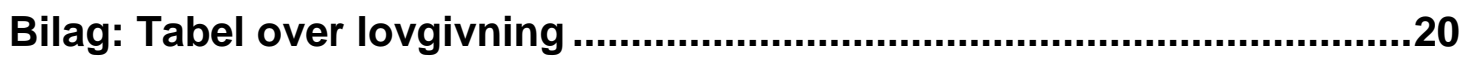




\section{Resumé på dansk}

De nordiske småsamfunds forståelse af MARPOL Annex VI om luftforurening fra skibe og omfanget af implementeringen af denne er emnet for det for-projekt, som rapporteres her. De nordiske småsamfund har små administrationer og bliver derfor ofte nødt til at finde andre og mere pragmatiske løsninger for implementering af konventioner end større lande.

Indmeldinger fra Grønland, Island og Færøerne viser, at de grundlæggende bestemmelser i MARPOL Annex VI vedrørende emissionsreducerende tiltag for stoffer, der nedbryder ozonlaget (ODS), nitrogenoxider $\left(\mathrm{NO}_{\mathrm{x}}\right)$ og svovloxider $\left(\mathrm{SO}_{\mathrm{x}}\right)$ allerede langt hen ad vejen er implementeret i Island og Færøerne, hvor havmiljølove m.m. rummer hjemmel til dette. I Grønland anvendes i begræenset omfang den eksisterende Landstingsforordning på området, men der er i projektets slutfase vedtaget en havmilljølov af Inatsisartut den 24. maj 2017, som træder i kraft d. 1 august 2017 og som rummer den nødvendig lovhjemmel.

Undersøgelsen har vist, at der ikke findes meget information om implementering af MARPOL Annex VI i mindre samfund. Det er vurderet, at de største udfordringer for Færøerne, Island og Grønland ved implementering af MARPOLs Annex VI er overvågning og flag- og havnestatskontrol. Færøeme, Grønland og Island er forskellige med hensyn til dette område da Island er medlem af en regional europæisk organisation for havnestatskontrol (Paris MoU), mens Færøerne og Grønland ikke er forpligtet af Danmarks medlemskab af denne organisation.

Der er en række muligheder for at implementere teknologier som kan lette byrden i forbindelse med havnestatskontrol, og der er mulighed for uddelegering af flagstatsopgaver, men der er ikke simple eksisterende "best practises" til rådighed for småsamfund.

- En række mindre lande uddelegerer flagstatsarbejde i forbindelse med et skibsregister til tredje parter som advokatkontorer og klasseselskaber;

- Der er ikke et specifikt måltal for omfanget af en havnestatskontrol, hvis man ikke har forpligtet sig i f.eks. Paris MoU. Omfanget kan da besluttes lokalt;

- Det er muligt at bruge internetbaserede risikoværktøjer til at udpege høj-risikoskibe for havnestatskontrol. Et risikoværktøj kunne være inspektionsdatabasen fra Paris MoU, hvoraf visse dele er offentligt tilgæengelige;

- På sigt kan elektronisk rapportering fra skibe begræense administrativt arbejde da en række data typisk fremsendes tre dage før anløb og her kan MARPOL VI data på svovl i brændstof eller udledning indgå. Det kan anbefales, at miljømyndigheder undersøger dette ved den myndighed, der står for overvågning af søfarten.

Udover anbefalingerne vedrørende kontrolfunktioner gøres der opmærksom på, at der for andre dele af MARPOL Annex VI, som ikke er en del af nærværende studie, kan der være udfordringer i forbindelse med flygtige organiske forbindelser (lastning af olie og bunkring m.m.), forbrændingsanlæg ombord på skibe, modtageanlæg og kvaliteten af brændstof, især svovl. Der er i rapporten fremlagt mulige projekter til at assistere MARPOL Annex VI implementering. 


\section{English summary}

The subject of the pre-project is the small Nordic communities' understanding of MARPOL Annex VI on air pollution from ships and the extent of its implementation. Faroe Islands, Greenland and Iceland have small administrations and therefore often the need to find other and more pragmatic solutions for the implementation of conventions than larger countries.

The information gathered from Faroe Islands, Greenland and Iceland shows that the basic provisions of MARPOL Annex VI regarding emission-reducing measures for ozone depleting substances (ODS), nitrogen oxides $\left(\mathrm{NO}_{\mathrm{x}}\right)$ and sulphur oxides $\left(\mathrm{SO}_{\mathrm{x}}\right)$ are already on the way to be implemented in Iceland and the Faroe Islands where marine environment laws etc. provides legal basis for this. Greenland is using the existing regulation in this area to a limited extent. After the finalization of this pre-project a new marine environment law has been adopted in the Parliament of Greenland that will enter into force on 1 August 2017.

The assessment showed there is only little information available regarding the implementation of MARPOL Annex VI in small communities. It is concluded for the Faroe Islands, Greenland and Iceland that the biggest challenges in implementing MARPOL Annex VI will be monitoring of compliance and flag and port state control. Faroe Islands, Greenland and Iceland are different in this respect as Iceland is a member of a regional European Port State Control Organization (Paris MoU), while the Faroe Islands and Greenland are not obliged by Denmark's membership of this organization.

There is a number of options for implementing technologies that can ease the burden of port state control and delegation of flag state tasks, but there are no simple existing "best practices" available to small communities.

- A number of smaller countries delegate flag state work in connection with a ship register to third parties as law firms and classification societies;

- There is no specific target for the extent of a port state control if a country has not committed itself in e.g. Paris MoU. The extent may then be decided locally;

- It is possible to use internet-based risk tools to identify high-risk vessels for port state control. A risk tool could be the inspection database from the Paris MoU, some of which is publicly available;

- In the long term, electronic reporting from ships may limit administrative work, as a number of datasets are typically transmitted three days before arrival, and here, MARPOL VI data on sulphur in fuel or emissions can be included. It is recommended that environmental authorities investigate this together with the authority responsible for monitoring of shipping.

In addition to the recommendations regarding control, attention is drawn to the fact that for other parts of MARPOL Annex VI, which are not part of this study, there may be challenges associated with volatile organic compounds (loading of oil and bunkering, etc.), combustion plants on-board ships, reception facilities and the quality of fuel, especially regarding sulphur. In the report possible projects are presented that may assist MARPOL Annex VI implementation. 


\section{Introduktion}

IMO's regler om forurening fra skibe er indeholdt i International konvention om forebyggelse af forurening fra skibe, kendt som MARPOL 73/78. MARPOL-konventionen og de 6 bilag til konventionen stiller en lang række krav om forhindring eller begrænsning af havforurening.

I 1997 blev MARPOL-konventionen ændret ved Protokol 1997, blandt andet med Annex VI om emissioner til luft med titlen "Regler for forebyggelse af luftforurening fra skibe". MARPOL Annex VI sætter grænser for skibes emissioner af stoffer, der nedbryder ozonlaget (ODS), for skibsmotorers udledning af nitrogenoxider $\left(\mathrm{NO}_{\mathrm{x}}\right)$ og for udledningen af svovloxider $\left(\mathrm{SO}_{\mathrm{x}}\right)$ enten ved begrænsning af svovlindholdet i brændstoffer eller ved rensning af røggasser.

Annex VI trådtei kraft den 19. maj 2005, men er løbendeændret. I oktober 2008 blev der indført (1) Tier I NO $\mathrm{x}$ krav til eksisterende motorer fra før 2000, (2) Tier II og III $\mathrm{NO}_{\mathrm{x}}$ emissionsnormer for nye motorer og (3) nye krav til svovlindholdet i brændstof begyndende fra juli 2010. Det reviderede Annex VI trådte i kraft den 1. juli 2010. I 2011 kom et kapitel til om udledning af drivhusgasser. Kravene om reduktion af luftforurening er nu gældende for $95 \%$ af verdens handelsskibe.

Nærværende for-projekt om implementering af MARPOL Annex VI har til formål at klarlægge, hvordan implementeringen af MARPOL Annex VI om skibes luftforurening bedst kan sikres i nordiske småsamfund. Som et for-projekt er det aftalt at fokusere på hovedreglerne om $\mathrm{SO}_{\mathrm{x}}$, $\mathrm{NO}_{\mathrm{x}}$ og ODS, som omtalt i sektion 2.1, og det betyder blandt andet at andre emissioner og kilder eller "Compliance monitoring and enforcement"-forhold ikke er detaljeret behandlet.

Projektet skal forbedre de nordiske småsamfunds forståelse af konventionens bilag og omfanget af implementeringen af denne. De nordiske småsamfund har små administrationer og bliver derfor ofte nødt til at finde andre og mere pragmatiske løsninger for implementering af konventioner end større lande. 


\section{Beskrivelse af MARPOL Annex VI og implementering i EU/EØS}

\subsection{Oversigt over MARPOL Annex VI reglernes indhold}

Bilag VI til MARPOL omhandler forebyggelse af luftforurening fra skibe og består af fire hovedkapitler og en række tillæg, hvortil kommer beslutninger i IMO, der publiceres løbende. Kapitel 1 omhandler generelt gyldigheden og Kapitel 2 Inspektion, certificering og kontrol. De regulerede udledninger er emnet for Kapitel 3 og omhandler følgende:

- Regel 12: Stoffer, der nedbryder ozonlaget (ODS)

- Regel 13: Nitrogenoxider $\left(\mathrm{NO}_{\mathrm{x}}\right)$

- Regel 14: Svovloxider og partikler ( $\left.\mathrm{SO}_{\mathrm{x}}\right)$

- Regel 15: Flygtige organiske forbindelser (VOC)

- Regel 16: Forbrænding bord på et skib

- Regel 17: Modtageanlæg

- Regel 18: Kvaliteten af brændstof

Et nyt kapitel, Kapitel 4, tilkom i 2011, trådte i kraft i 2013 og udgør IMOs håndtering af udledning af drivhusgasser. I det fokuseres på reduktioner af $\mathrm{CO}_{2}$ gennem krav til forbedring af energieffektiviteten for nye og eksisterende skibe.

Denne gennemgang beskriver de tre reguleringer i afsnit 12-14. De øvrige dele af MARPOL Annex VI (reglerne 15-18) om flygtige organiskeforbindelser, forbrændingsanlæg bord på skibe, modtageanlæg i havne og kvaliteten af brændstof, tages i betragtning i forhold til et eventuelt hovedprojekt. ${ }^{1}$

\subsection{Reglerne om ODS, nitrogenoxider og svovl}

I dette afsnit beskrives MARPOL reglerne for emissionerne af stoffer, der nedbryder ozonlaget (ODS), nitrogenoxider $\left(\mathrm{NO}_{\mathrm{x}}\right.$ ) og svovloxider $\left(\mathrm{SO}_{\mathrm{x}}\right)$. Udslippet af partikler hænger sammen med emissionen af $\mathrm{SO}_{2}$ og er ikke direkte reguleret. Der er mulighed for at udpege emissionskontrolområder ("Emission Control Areas" forkortet ECA), hvor særlige forpligtelser vedrørende skibes emission er sat i kraft for at kontrollere luftforurening forårsaget af enten svovl (SECA-områder), eller $\mathrm{SO}_{\mathrm{x}}$ og $\mathrm{NO}_{\mathrm{x}}$ (ECA-område), som f.eks. i Nordsøen og i Østersøen. I det nordamerikanske ECA reguleres partikler også.

\section{Ozonnedbrydende stoffer}

I henhold til MARPOL Annex VI regel 12 er forsætlige emissioner af ozonlagsnedbrydende stoffer forbudt i både internationale og nationale farvande pga. klimaeffekten. Installationer taget i brug efter den 19. maj 2005 må ikke indeholde ozonlagsnedbrydende stoffer, med undtagelse af hydrochlorofluorocarbon (HCFC) frem til januar 2020. Derefter skal dette udstyr og systemer afleveres til specielle udvalgte modtageranlæogi de enkelte lande, som har ratificeret MARPOL i 2020. Alle skibe underlagt MARPOL Annex VI er forpligtet til at have en oversigt over ODS ombord på skibet, som en del af deres certifikater.

\section{Nitrogenoxider (kvæelstof)}

\footnotetext{
${ }^{1}$ Specifikke krav kan findes i supplement til MARPOL Consolidated Edition 2011 (IMO 2015).
} 
Grænserne fastsat i MARPOL Annex VI regel 13 gæelder for dieselmotor og afhænger af motorens maksimale driftshastighed. Tier I og Tier II er globale forskrifter, mens Tier III-standarder kun gælder for emissionskontrolområder.

TIER I (Globale regler) Anvendelse af marine dieselmotorer, der installeres på et skib bygget mellem den 1. januar 2000 og før den 1. januar 2011, er forbudt, medmindre emissionen af kvælstofoxid fra motoren følger den øverste kurve på grafen (se nedenfor).

TIER II (Globale regler) Anvendelse af marine dieselmotorer, der installeres på et skib bygget den 1. januar 2011 eller senere, er forbudt, medmindre emissionen af kvælstofoxid følger TIER II-kurven på grafen (se nedenfor). Dette svarer til ca. $15-20$ pct. reduktion i forhold til TIER I.

TIER III (ECA-regler) Anvendelsen af marine dieselmotorer, der installeres på et skib bygget den 1. januar 2016 eller senere, og som opererer i et ECAområde, skal reducere $\mathrm{NO}_{\mathrm{x}}$-emissionerne med ca. 80 pct. i forhold til TIER I. Se nederste kurve på grafen (se nedenfor).

Derudover er der regler for motorer installeret mellem 1. januar 1990 og 1. januar 2000, såfremt de har en effekt på mere end $5.000 \mathrm{~kW}$. Disse skal overholde kravene i TIER I.

Disse kriterier specificeres for den enkelte motor, efterprøves og certificeres hos motorproducenten af klasseselskaber, men det er myndighedernes opgave at tilse, at skibe under ens flag og i ens område har motorer med en gyldig certificering.

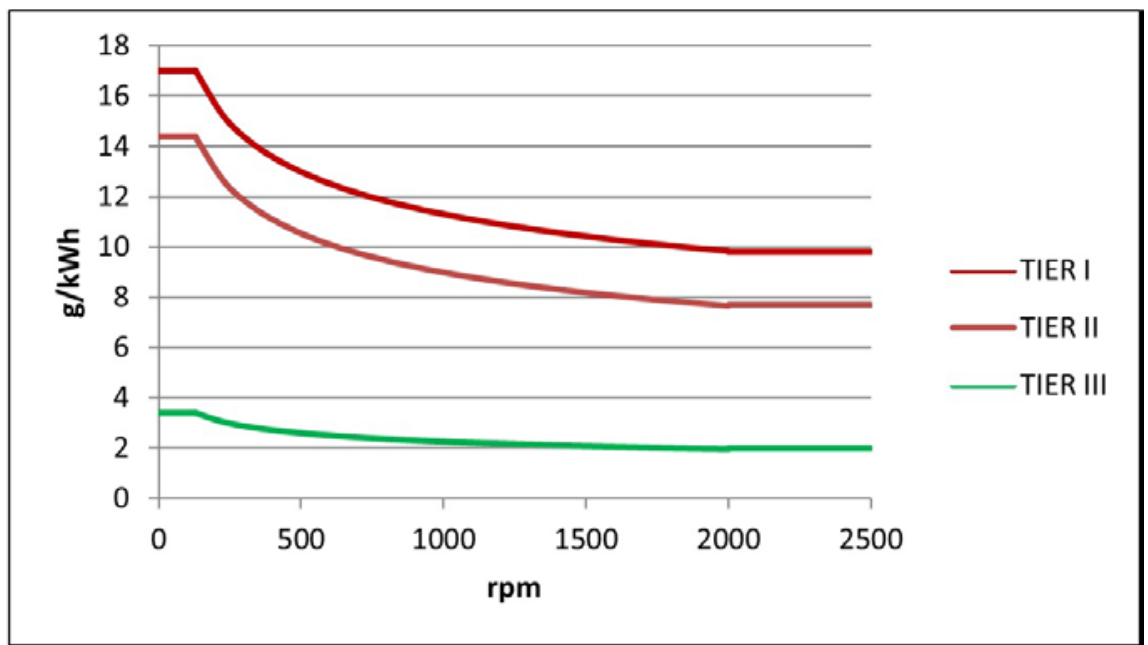

Figur 1: NOx emissionsgrænse som funktion af motorens effekt. Kilde: Søfartsstyrelsen (2017)

\section{Svovloxider og partikler}

Reduktion af $\mathrm{SO}_{\mathrm{x}}$ udledning er reguleret i MARPOL Annex VI reg. 14. Gennem begræensning af svovl i brændstoffet. Globalt må svovlindholdet i maritime brændstoffer ikke overstige følgende græenseværdier opgivet i vægtprocent:

- $\quad$ pr. 1. januar 2012: 3,5\%

- pr. 1. januar 2020:0,5\% 
Det er i 2016 besluttet i IMO at 2020 begræensningen står ved magt. Der er flere SECA med lavere græenseværdier for svovl i brændstof opgivet i vægtprocent:

- $\quad$ pr. 1. juli 2010: $1,00 \%$

- pr. 1. januar 2015: 0,10\%

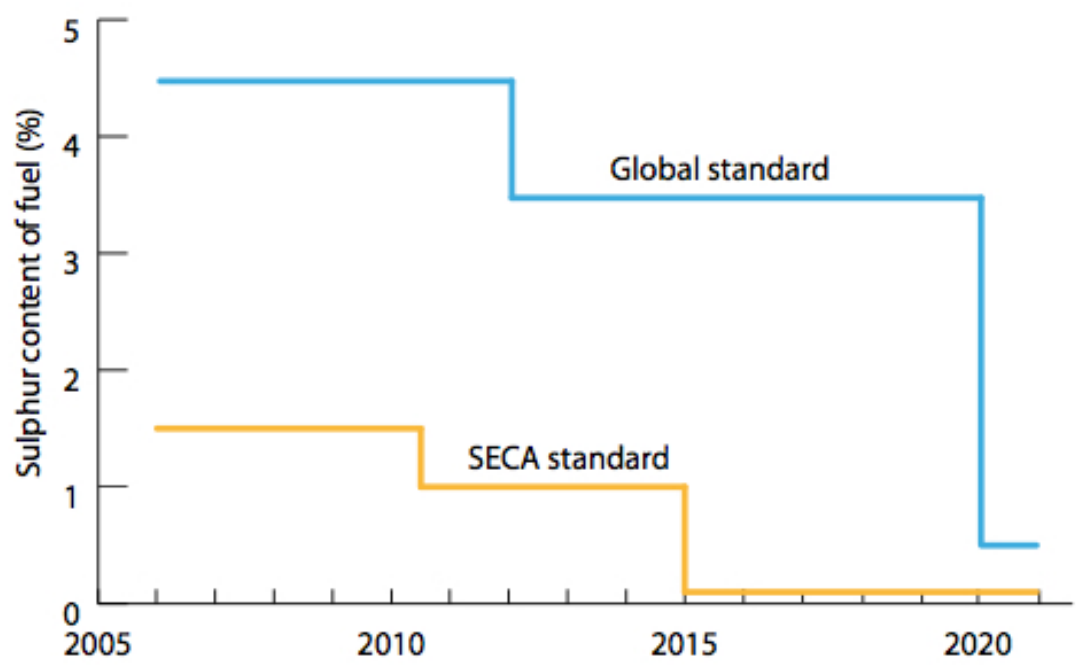

Figur 2: Reduktion af svovl i brændstof for skibe (IMO 2013). I EU havne gædder 0,1\% grænsen.

Der er i EUs Svovldirektiv (EU 2005/33/EC) også regler om max. 0,1\% svovl i brændstof, når et skib ligger forankret i EU/ EØS havne og et krav til svovlindholdet i passagerskibes brændstof på højst 1,5\%, når disse er i fast rute mellem EU/ EØS havne.

Ud over at bruge brændstoffer med et tilladt lavt svovlindhold er en anden metode til overholdelse af svovlreglerne at anvende røggasrensning og fjerne svovl med en røgvasker.

MARPOL Annex VI regel 4.1 tillader, at skibene som alternativ må bruge reduktionsteknologier til at nedbringe $\mathrm{SO}_{\mathrm{x}}$ emissioner og i stedet rense udstødningsgassen med et "Exhaust Gas Cleaning System" - en røgvasker eller "scrubber". Forskrifter for udledning af vaskevand fra røgvaskere til havet er beskrevet i IMO MEPC.184(59) og indeholder grænseværdier med hensyn til turbiditet, pH m.m. Der kan være lokale eller nationale regler om vandkvalitet, som er strammere end IMOs udledningsgræenser.

\subsection{Implementering af MARPOL Annex VI i EU/EøS}

Danmark har ratificeret MARPOL konventionerne og implementeret dem i forskellige nationale love. Lovgivningen om miljø i skibsfarten er ofte delt mellem et miljøministerium med det overordnede ansvar for miljøet og et "implementeringsministerium" med ansvar for inspektion og kontrol, som kan være et erhvervs-, transport- eller forsvarsministerium (kystbevogtning). Gennemførelsen af MARPOL Annex VI bliver udført i fællesskab af miljømyndigheder og søfartsmyndigheder, i Danmark Miljøstyrelsen og Søfartsstyrelsen. I diagrammet kan man se hvordan Danmarks regulering af MARPOL Annex VI er bygget op. 


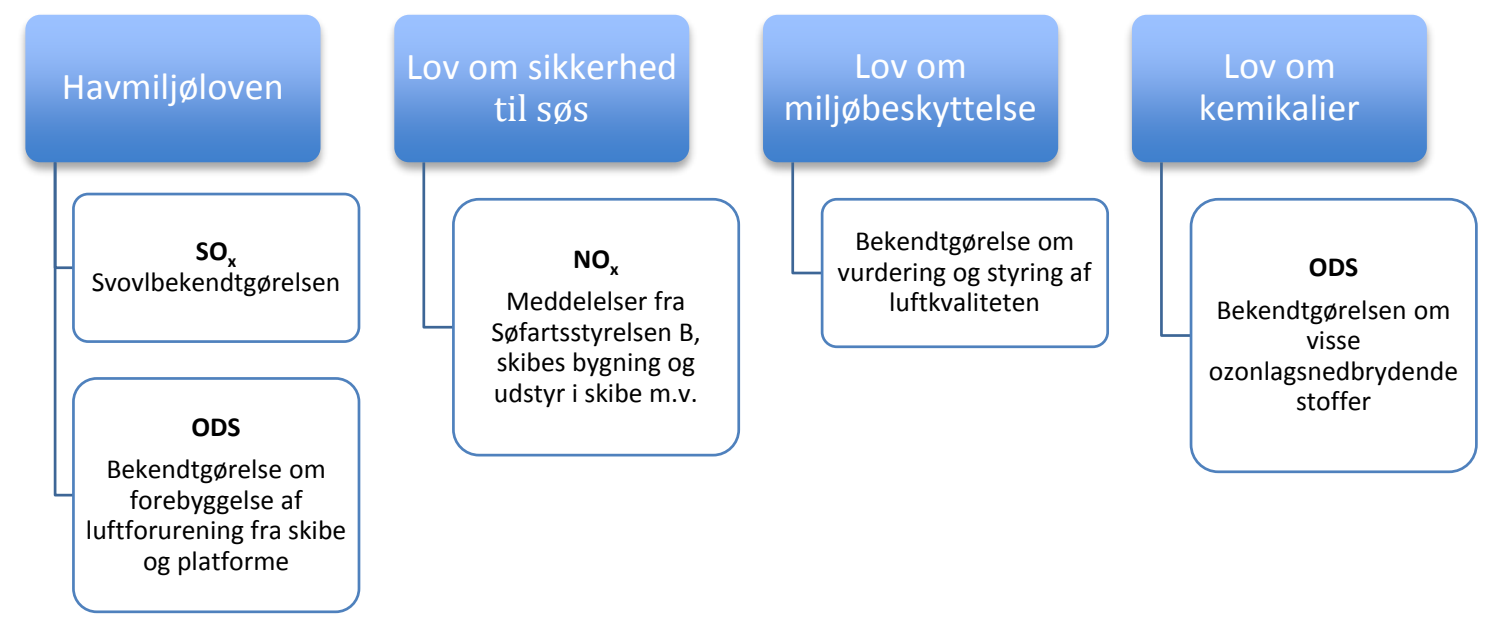

For lande, som er en del af EU (Danmark) eller EØS (Norge/Island), vil en del af MARPOL Annex VI ske ved implementeringen af direktiver og forordninger, som vedtages på EU niveau. Dette er beskrevet i bilagstabellen for Danmark og Island. Der kan også være særlige mål for reduktioner vedtaget i andre fora, f.eks. Arktisk Råd, OSPAR/ HELCOM, Gøteborgprotokollen.

I Norge vil der være særlige regelsæt for skibsfarten, da norsk territorium både rummer et SECA syd for $62 \mathrm{~N}$, et arktisk område med særlig status (Svalbard) og et område med lovgivning i overensstemmelse med svovldirektivet fra EU. Der er i Norge en særskilt afgift på udslip af $\mathrm{NO}_{\mathrm{x}}$ fra motorer og gasafbræending. Denne afgift omfatter udslip i Norge ogi norsk territorialfarvand. Denne afgift er $i$ et betydeligt omfang ført tilbage til industrien i tekniske udviklingsprogrammer, som blandt andet har ledt til norsk styrke indenfor sejlads med batteri og med naturgas (LNG).

\section{Implementering i Island, Færøerne og Grønland}

De grundlæaggende forudsætninger for at inkludere MARPOL kravene i national lov er allerede til stede i Island, og Færøerne, hvor havmiljølove rummer hjemmel til dette. I Grønland er den nuværende landstingsforordning for havmiljøet beskrevet, mens et udkast til ny havmiljølov ikke er medtaget.

Der er givet en omfattende oversigt på de tre hovedområder i tabellerne i bilag 1, som er baseret på direkte indmeldinger fra Grønland, Island og Færøerne. Den forvaltningsmæssige struktur og tilgangen til lovgivning varierer noget fra land til land.

- Grønland er formelt undtaget fra Danmarks tiltrædelse af MARPOL Annex VI. Grønland er imidlertid langt i forhold til at kunne vedtage en Havmiljølov i 2017, som vil rumme den nødvendige lovhjemmel. Hvis skulle det blive relevant at arbejde videre indenfor eksisterende lovgivning, kan MARPOL Annex VI indarbejdes i den eksisterende Landstingsforordning. ${ }^{2}$

- Island har under EØS aftalen implementeret en række EU direktiver og forordninger på området, og er således langt fremme lovgivningsmæssigt i forhold til MARPOL Annex VI, men har endnu ingen regler om NOx tilsvarende Regulation 13 i MARPOL Annex VI.

2 Inatsisartut vedtog d. 24. maj en Havmiljølov for Grønland. 
- Færøerne har en havmiljølov, som implementerer en række af MARPOL Annex VIs regler og har derfor frasagt sig undtagelsen fra Danmarks tiltrædelse af annexet. Færøsk lovgivning har umiddelbart hjemmel til de fleste regler, mens der endnu er fă regler for kontrol af $\mathrm{NO}_{\mathrm{x}}$.

\section{Grønland}

Grønland har generelt få regler på havmiljøområdet. Regler står i Landstingsforordning nr. 4 af 3. november 1994 om beskyttelse af havmiljøet med senere ændringer. Dog findes der i Landstingsforordningen ( $\S 25$ ) en lovhjemmel til at udstede bekendtgørelser i relation til MARPOL Annex VI. Landsstyret kan til beskyttelse of det grønlandske søterritorium fastsætte regler om særlige foranstaltninger, herunder krav til brændstof, om bord på skibe med henblik på begræensning af luftforurening.

På for-projektets tidspunkt har Grønland ingen regler mht. $\mathrm{SO}_{\mathrm{x}}, \mathrm{NO}_{\mathrm{x}}$ eller ODS i relation til MARPOL Annex VI. Der er i bilaget taget udgangspunkt i eksisterende lovgivning. Det er i Grønland politiet og forsvaret, som kontrollerer overholdelse af bestemmelserne i Landstingsforordningen, og landstyret kan udstede særlige regler om kontrollen. Udenfor grønlandsk territorialfarvand gædder dansk havmiljølov, som håndhæves af den danske flåde.

Island

Ministeriet for miljø og naturressourcer har ansvaret for lovgivning om miljø i skibsfarten, inkl. implementering af MARPOL konventionen. Det overordnede ansvar for gennemførelsen og kontrol ligger hos Umhverfisstofnun (Miljøstyrelsen), mens Samgöngustofa (Icelandic Transport Authority ${ }^{3}$ ) har ansvaret for inspektion af skibenes udstyr i forbindelse med forebyggelse af forurening, herunder certifikater og havnestatskontrol. Kystvagten er ansvarlig for overvågning af farvandet omkring Island og informerer Miljøstyrelsen om forurening eller mistanke om forurening af havområder eller kyst.

Ministeriet for miljø og naturressourcer fastsætter regler/ forordninger vedrørende havmiljøet på grundlag af lov nr. 33/ 2004 om forebyggelse af forurening af havområde og strand. Island har ikke ratificeret MARPOL Annex VI, men ministeriet for miljø og naturressourcer har begyndt processen for ratifikation.

Island opfylder allerede MARPOLs krav mht. $\mathrm{SO}_{\mathrm{x}}$ og ODS. Med implementering af Direktiv 2012/33/EU om svovlindhold i visse flydende brændstoffer i den nationale lovgivning er de fleste emner i MARPOL regel 14 dæakket. Dog mangler en særlig regulering vedrørende udledning af vaskevand fra røgvaskere og modtagelsen i havne i Islands lovgivning. Yderligere mangler der implementering af $\mathrm{NO}_{\mathrm{x}} \mathrm{krav}$.

\footnotetext{
${ }^{3}$ Samgöngustofa på islandsk. Officiel engelsk oversættelse er "Icelandic Transport Authority".
} 

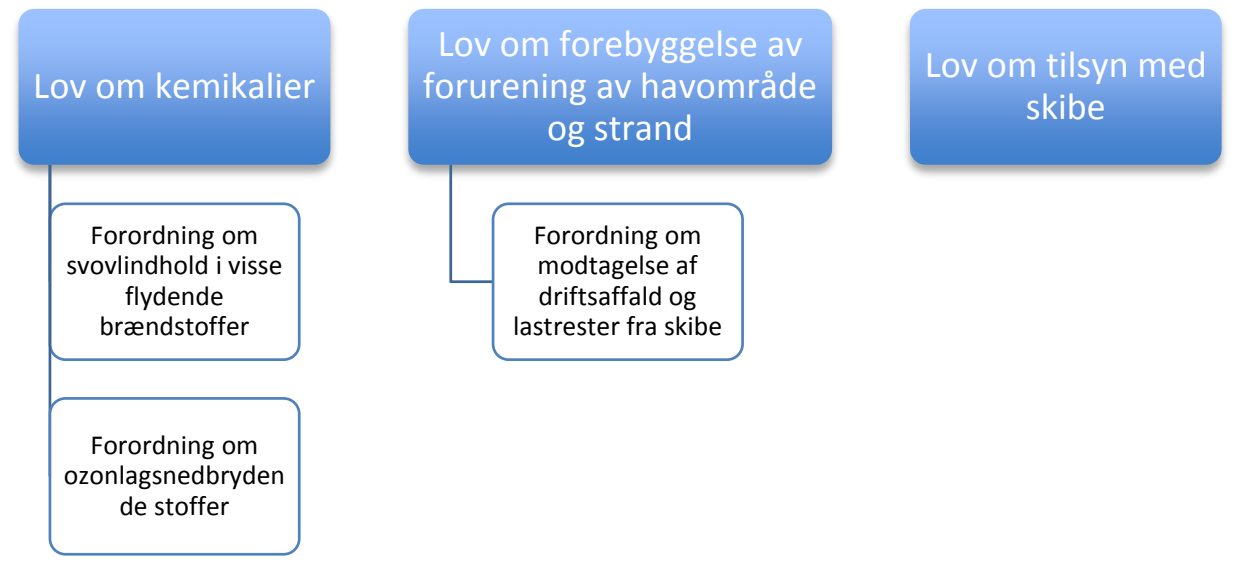

Færøerne

Færøerne har administrationen af sagsområderne for miljø, havmiljø og sikkerhed til søs og har færøsk lovgivning på alle tre områder. For miljø og havmiljø er færøske bekendtgørelser sat i kraft, og for sikkerhed til søs bliver tekniske forskrifter fra den danske søfartsstyrelse sat i kraft. Som i Danmark er lovgivningen om miljø i skibsfarten delt mellem myndigheden med det overordnede ansvar for miljøet og en "implementeringsmyndighed" med ansvar for inspektion og kontrol, som udføres af den færøske søfartsstyrelse. I Færøerne er der et samarbejde imellem miljømyndigheden og søfartsmyndigheden, og desuden udfører kystbevogtning tilsynsopgaver på fiskeskibe for miljømyndigheden (affald, kloakspildevand etc.).

Den første færøske havmiljølov var "Anordning om ikrafttræden af lov om beskyttelse af havmiljøet" fra 2001 (som implementerede dansk havmiljølov). Den blev hurtigt efterfulgt af en færøsk havmiljølov fra 2005 (Løgtingslóg nr 592005 um verju av havumhvørvinum) stadig baseret på den daværende danske havmiljølov, dog med et par ekstra kapitler f.eks.: Kap 8 om luftforurening. Her står der i §15, at ministeren kan, bl.a. for at fremme internationale konventioner, bekendtgøre regler om særlige ordninger for at mindske luftforurening fra skibe og platforme, bl.a. krav til brændstof. Dvs. at ministeren har hjemmel til at udstede bekendtgørelser vedrørende luftforurening fra skibe.

Færøerne har regler om ozonnedbrydende stoffer og har valgt at indsætte et producent/ importansvar i stedet for modtageanlæg i havne. Den færøske søfartsstyrelse er ansvarlig for reglerne angående de tekniske installationer om bord i færøske skibe med hensyn til $\mathrm{NO}_{\mathrm{x}}$ bestemmelse. Som næunt i Bilag 1 under $\mathrm{NO}_{\mathrm{x}}$ er Bekendtgørelse om Meddelelser fra Søfartsstyrelsen B, skibes bygning og udstyr i skibe m.v. sat i kraft på Færøerne ved Kunngerð frá 1. mai 2016 frá Sjóvinnustýrinum um byggi- og útgerðarkrøv o.a., (Bekendtgørelse om skibets bygning og udstyr), som har hjemmel i den færøske Løgtingslóg nr. 165 fra 2001 um trygd á sjónum, §§17-21 (Lagtingslov om sikkerhed til søs). Reglerne håndhæves efter aftale mellem den færøske søfartsstyrelse og klasse-selskaberne. 

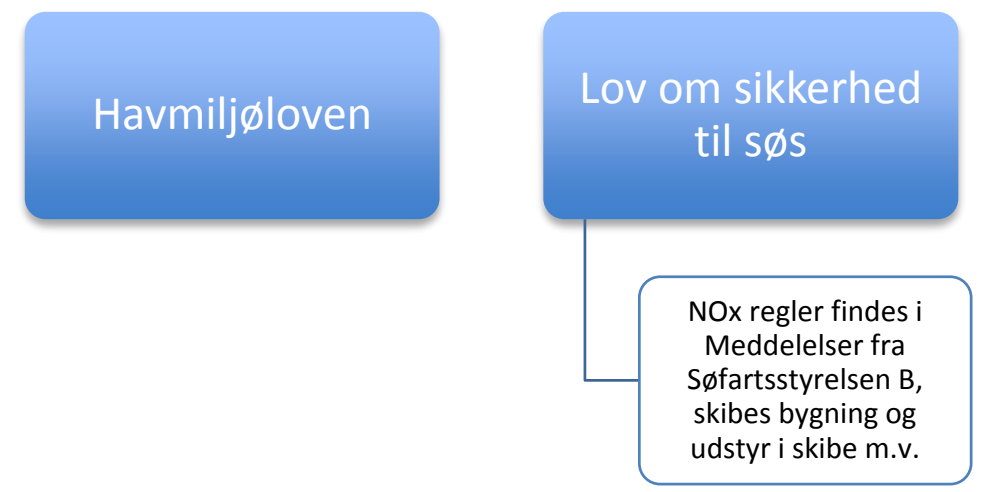

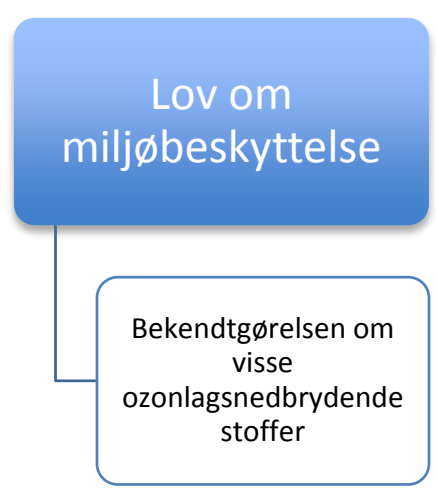

\section{Beskrivelse af hvordan regler simplest overholdes}

Internationale konventioner med deres tilhørende regelværk og vejledninger rummer sjældent muligheder for at tilslutte sig kun udvalgte dele, selvom der i en ratifikationsproces gives muligheder for at undtage særlige områder, både geografisk og emnemæssigt.

\subsection{Information til råd og vejledning}

IMO (2013) har udgivet et dokument om implementering af MARPOL generelt, "MARPOL How to do it: Manual on the practical implications of ratifying and implementing MARPOL 73/78" 4 , som er en manual om de praktiske konsekvenser af at ratificere og gennemføre MARPOL kravene. Manualen er forholdsvis bredt anlagt og adresserer især institutionelle og juridiske udfordringer. Den er ikke synderligt specifik om implementering af Annex VI.

IMO udgiver jæevnligt en konsolideret og opdateret version af alle MARPOL annexene samlet (senest i 2011), som suppleres løbende (senest i 2015). Der er også udgivet en mere specifik bog "MARPOL annex VI and NTC 2008 with guidelines for implementation" 5, som er en god opsamling af IMOs beslutninger på området, men også meget teoretisk og teknisk.

På det mere praktiske plan har IMO tekniske støtteprogrammer for implementering af mange af sine regelsæet, men desværre ikke for mange for de relevante dele af MARPOL VI. Imidlertid arbejder IMO med et projekt, GloMEEP, som handler om at finde en strategi til at støtte nationale regeringer $\mathrm{i}$ at forfølge relevante juridiske, politiske og institutionelle reformer til en effektiv gennemførelse af andre dele af MARPOL VI: energieffektivitetskravene i Kapitel 4. Kurser og workshops på bl.a. vejledning til inkorporering af MARPOL Annex VI i national lov, blev afholdt i GloMEEPs "lead pilot" lande (Argentina, Kina, Georgien, Indien, Jamaica, Malaysia, Marokko, Panama, Filippinerne og Sydafrika). Projektet har til formål at støtte lande i at styrke og udvikle nationale lovgivningsmæessige rammer i forbindelse med forebyggelse af luftforurening og udledning af drivhusgasser fra skibe, og dets resultater og retningslinjer vil blive offentliggjort i juli 20176. Yderligere information findes på GloMEEPs hjemmeside7, herunder muligheden for at kontakte projektkoordinatorer vedrørende kommende kurser.

\footnotetext{
${ }^{4}$ http://www.imo.org/en/Publications/Documents/Newsletters\%20and\%20Mailers/Mailers/IB 636E.pdf

${ }^{5} \mathrm{NTC}=\mathrm{NO}_{\mathrm{x}}$ Technical Code

${ }^{6}$ Mail fra Edmund Hughes, IMO, 14. marts 2017

${ }^{7}$ http://glomeep.imo.org/
} 
En præesentation på en GloMEEP workshop i december sidsteår giver et foreløbig overblik over politiske og strategiske spørgsmål, som kan være nødvendigt at overveje fra en regering, der gennemfører bestemmelserne i MARPOL Annex VI, hvor den altoverskyggende anbefaling er, at der skal være klare og veldefinerede ansvarsområder for de deltagende institutioner, og at en enkel myndighed skal have hovedansvaret for gennemførelsen.

Der er mulighed for at trække på samarbejder gennem organisationer som Nordisk Ministerråd, Arktisk Råd, Paris MoU, og gennem netvæerksdannelser og direkte kontakt til andre landes myndigheder, f.eks. i andre småsamfund, Danmark ${ }^{8,} 9$ eller Norge, som kan formidle viden om tiltag i deres område.

\subsection{Andre småsamfund}

Generelt har undersøgelsen vist, at der ikke findes særlig meget information om implementering af MARPOL Annex VI i mindre samfund. Det nærmeste man kommer, er IMOs Technical Cooperation enhed for udviklingslande, som Grønland, Færøerne og Island naturligvis ikke falder under, men der er i dette program en del indsatser overfor "Small Island Developing States" (SIDS), som også har små administrationer.

Et casestudie fra Samoa (Solofa 2009) viste, hvor vigtigt det er, at miljølove og skibsfartslove er klart definerede med hensyn til ansvar for lovgivning. Overlap mellem lovene kan forårsage operationelle konflikter mellem de involverede myndigheder, hvilket også var konklusionen på GloMEEPs workshop næunt ovenfor.

Modtagefaciliteter er ikke et emne for nærværende rapport, men indenfor de seneste par år (IMO 2015) er det under andre MARPOL annexer godkendt, at SIDS indgår regionale aftaler mht. placering af modtagefaciliteter for at mindske den økonomiske og administrative byrde på havne og myndigheder.

\subsection{Indsats på inspektion, certificering og kontrol}

Det er, som nærnt tidligere, ikke muligt at ændre på en konventions gyldighedsområde, når først man har ratificeret den eller tilsluttet sig en ratifikation, så en konvention gæalder for de skibe og under de omstændigheder, som er næunt i den. Når det er sagt, bør de elementer af MARPOL VI, som har med inspektion m.m. at gøre, kunne prioriteres.

Der er ikke så stor forskel på den trafik, som Island, Grønland og Færøerne ser i havnene, med hensyn til skibstyper. I Island, Grønland og Færøerne er fiskefartøjer en væentlig del af trafikken, dog også blandet med krydstogtskibe/passagerskibe, mindre containerskibe, feederskibe og stykgodsskibe, tankere (primært for import af bræendstof), og i et fătal havne tørlastskibe med massegods. Derimod er Island, Færøerne og Grønland ret forskellige med hensyn til juridiske forhold omkring skibsregistre, territorialfarvand, EEZ og håndhævelsen af regler indenfor flagstats- og havnestatsforhold. Det er her forsøgt at præesentere de generelle forhold, der særligt kan adresseres som et småsamfund.

\section{Flagstatskontrol}

Når et skib fører et lands flag og er opført i skibsregisteret, er flagstaten ansvarlig for at sikre, at skibet overholder nationale love, inklusive de internationale regelsæt som landet har tilsluttet sig og implementeret, både når det sejler i eget farvand og internationalt.

\footnotetext{
${ }^{8}$ Telefonsamtale med Dorte Kubel, Miljøstyrelsen, 8. marts 2017.

${ }^{9}$ Telefonsamtale med Peter Krog-Meyer, Søfartssyrelsen, 10. marts 2017.
} 
Der gælder også for MARPOL Annex VI, hvor skibes certifikat på luftemissioner (IAPPInternational Air Pollution Prevention) skal udstedes, verificeres/kontrolleres og fornys af flagstaten. IAPP certifikatet indeholder oplysninger om udstyr med ODS på skibe, motorens specifikation vedrørende $\mathrm{NO}_{\mathrm{x}}$ udledning, og om skibets $\mathrm{SO}_{\mathrm{x}}$ information, dvs. om der er en røgvasker installeret, og certifikatet skal fornyes senest hvert femteår. Den indsats, som et småsamfund er nødt til at gøre på flagstatsområdet for at leve op til sine forpligtelser, kan i et betydeligt omfang udliciteres til tredje part og/ eller finansieres af gebyrer.

Hverken Island, Færøerne eller Grønland er beliggende i et ECA, men skibe, som er opført i et lands register, skal også overholde disse regler, hvis de sejler i et ECA.

\section{Havnestatskontrol}

Når et skib med et andet lands flag anløber havne på ens territorialområde, kan den relevante myndighed foretage en havnestatskontrol, hvor en inspektør kontrollerer skibets certifikater og almene tilstand. Man kan igangsætte en mere detaljeret inspektion, hvis der er begrundet mistanke om ulovlige forhold. En række skibe skal i EU underkastes en udvidet inspektion med basis i EU direktivet (2009/ 16/ EC) på området:

- Skibe med højrisikoprofil

- Passagerskibe, olietankskibe, gas- eller kemikalietankskibe eller bulkskibe, som er over 12 år gamle

- Skibe med højrisikoprofil eller passagerskibe, olietankskibe, gas- eller kemikalietankskibe eller bulkskibe, som er over 12 år gamle, i tilfælde af topprioriteringsfaktorer eller uventede faktorer ${ }^{10}$

- Skibe, der underkastes fornyet inspektion efter et adgangsforbud udstedt i henhold til Direktivets artikel 16.

Det er den fælles organisation for havnestatskontrol, Paris MoU (Paris Memorandum of Understanding), som Island og Danmark er medlem af, der fastlægger skibes risikoprofil på basis af resultater fra en rakke års inspektioner. Der er adgang til principperne for risikoberegning på Paris MoUs hjemmeside (www.parismou.org) og til en generel risikoberegner for skibe i det Europæiske Søfartsagentur, EMSA (2017), som kan udpege højrisikoskibe.

Specielt med hensyn til MARPOL Annex VI planlægger Paris MoU landene en intensiveret inspektionskampagne i 2018.

Det skal erindres, at den almindelige form for kontrol med skibe er flagstatens skrivebordskontrol af registreringer og certificeringer, som sker med alle skibe med statens flag, og havnestatens fysiske inspektion ombord ved anløb til en havn, som er en stikprøvekontrol. Ved begrundet mistanke om ulovligheder har en stat (kyststaten) også ret til at borde et skib og inspicere det under passagen i sit farvand, men dette er en yderst sjæalden begivenhed, som i miljøsammenhæeng primært er blevet anvendt ved store olieforureninger. I de allerseneste år er nogle lande begyndt at overvåge svovlforurening på søterritoriet. Danmark gennemfører analyser af $\mathrm{SO}_{\mathrm{x}}$ i røgfaner fra skibe ved hjælp af droneteknologi og bro-monterede sensorer, og andre lande anvender fly.

${ }^{10}$ En nærmere forklaring af disse faktorer findes i EU direktivet (2009/16/EC ) bilag I, del II. (http://eur-lex.europa.eu/legal-content/DA/TXT/?uri=celex:32009L0016) 
Det forventes, at der fremover vil komme yderligere fokus på "Compliance monitoring and enforcement" både indenfor IMO området generelt, men også i forbindelse med EUs regelsæt om "Measurement, reporting and verification (MRV)", selvom sidstnæunte (endnu) ikke er obligatorisk for de tre luftemissioner, der er emnet for denne rapport.

\section{Konklusioner og anbefalinger}

\subsection{Overordnet konklusioner}

For mindre nationer og småsamfund er de primære problemstillinger med at opfylde MARPOL Annex VI at etablere lovgrundlaget og de institutionelle rammer. De grundlæaggende bestemmelser i MARPOL Annex VI vedrørende emissionsreducerende tiltag for ODS, $\mathrm{NO}_{\mathrm{x}}$ og $\mathrm{SO}_{\mathrm{x}}$ er allerede langt hen ad vejen implementeret i Island og Færøerne, hvor havmiljølove m.m. allerede rummer hjemmel til dette. I Grønland anvendes i den eksisterende Landstingsforordning på området, mens der ligger et udkast til havmilljølov (per. 1 august 2017 ophøjet til lov), som vil kunne implementere MARPOL Annex VI. Overordnet set vurderes det dog, at der er eksisterende lovhjemmel, som gør det muligt for både Island, Færøerne og Grønland at udarbejde de nødvendige lokale regler, der opfylder MARPOLs Annex VI.

IMO stiller en række dokumenter til rådighed for MARPOL implementeringsprocessen, men de begrænsede erfaringer der er fra implementering i mindre ø-samfund (SIDS) fokuserer mere på de institutionelle udfordringer end på de praktiske. Der er ikke meget eksisterende viden i form af vejledninger og skabeloner, som henvender sig til samfund med små administrationer, men der findes dog administrative og teknologiske tiltag, som kan mindske byrden, f.eks. gebyrer og diverse værktøjer til kontrol. Der er et behov for yderligere information indenfor disse områder, som opfylder visse minimumskrav til kontrollerne (EU; Paris MoU) eller som leder til et kontrolniveau fastsat i national lov/ bekendtgørelse afhængig af land. Som nævnt kan en øget brug af egenkontrol eller uddelegering af kontrollen til tredje part, typisk private aktører, også bruges til at lette den administrative byrde. Lokal udveksling af "best practises" vil derfor være særlig vigtigt.

\subsection{Tiltag}

I for-projektet er udarbejdet en foreløbig liste med tiltag, der kan lette processen med at implementere MARPOLs Annex VI, som er vist i tabel 1. Indenfor teknologiske tiltag er der senest tilkommet drone- og sensorteknologier, som in situ hel- eller halvautomatisk kan udpege skibe, som ikke overholder svovlkravene. Der er også detektorer på markedet for ODS test ombord. Endelig er der begyndt at komme elektroniske logbøger m.m. som på sigt vil kunne forsimple og forbedre havnestatskontrollen.

Island, Færøerne og Grønland ikke er lige langt i deres forberedelse på MARPOL Annex VI i og med, at de er ret forskellige med hensyn til juridiske forhold omkring skibsregistre, territorialfarvand, EEZ og håndhævelse af regler indenfor flagstats og havnestatsforhold.

I andre dele af MARPOL Annex VI kan der væere udfordringer i forbindelse med flygtige organiske forbindelser (lastning af olie og bunkring m.m.), forbrændingsanlæg ombord på skibe, modtageanlæg og monitering af kvaliteten af brændstof, især svovl. 
Tabel 1: Check liste for handlingsmuligheder for myndigheder.

\begin{tabular}{|c|c|}
\hline Handling & Kommentar \\
\hline Netværk og vidensdeling & $\begin{array}{l}\text { Der udarbejdes en liste med kontaktoplysninger på relevante } \\
\text { ressourcepersoner i Færøerne, Island og Grønland for } \\
\text { optimalt udnyttelse af viden og vidensdeling. }\end{array}$ \\
\hline Nødvendig hjemmel & $\begin{array}{l}\text { Der kan laves en juridisk afklaring om der er tilstrækkelig } \\
\text { lovhjemmel til at regulere i henhold til MARPOL Annex VI } \\
\text { (især Grønland). }\end{array}$ \\
\hline Udkast og skabeloner & $\begin{array}{l}\text { Der udveksles skabeloner i gruppen og udarbejdes udkast til } \\
\text { lokale regler om } \mathrm{SO}_{\mathrm{x}}, \mathrm{NO}_{\mathrm{x}} \text { og ODS. Da disse regler kan være } \\
\text { teknisk komplicerede, bør andre relevante myndigheder og } \\
\text { lokale søfartskyndige inddrages. }\end{array}$ \\
\hline $\begin{array}{l}\text { Uddelegering af } \\
\text { flagstatsarbejde }\end{array}$ & $\begin{array}{l}\text { En række mindre lande overlader et skibsregisters } \\
\text { implementeringsarbejde til tredje part f.eks. } \\
\text { klassifikationsselskaber (Bureau Veritas, DNV GL, m.m.). } \\
\text { Det bør afklares om muligheden for at tredje part kan udføre } \\
\text { kontrol er relevant, om der kan opkræeves gebyr og hvem der } \\
\text { skal have ansvaret for kontrol med overholdelse af regler. }\end{array}$ \\
\hline Havnestatskontrol & $\begin{array}{l}\text { Der er ikke et specifikt måltal for havnestatskontrol, hvis } \\
\text { man ikke er med i en MoU. Omfanget kan fastsættes efter } \\
\text { konsultationer lokalt. }\end{array}$ \\
\hline $\begin{array}{l}\text { Inspicer kun de vigtige } \\
\text { skibe }\end{array}$ & $\begin{array}{l}\text { Undersøg om det er muligt og relevant at bruge Paris MoU } \\
\text { eller EMSA risikovæerktøj til at udpege høj-risikoskibe. }\end{array}$ \\
\hline $\begin{array}{l}\text { Overveje automatisk } \\
\text { indrapportering }\end{array}$ & $\begin{array}{l}\text { En række data fremsendes typisk tre dage før anløb (ETA72) } \\
\text { til søfartsmyndigheder, og her kan MARPOL VI data på svovl } \\
\text { i brændstof eller udledning indgå (der er arbejde i gang i EU } \\
\text { på området). }\end{array}$ \\
\hline
\end{tabular}

På den lidt længere bane kan der være behov for at undersøge:

- Afklaring af behovet for modtageanlæg. Er der eksisterende som kan anvendes, og hvem har ansvaret for dette.

- Afklaring om hvorledes der skal reguleres og kontrolleres for svovlindholdet i brændstoffet og også vil acceptere en anden metode til overholdelse af svovlreglerne via reduktion i udledning (røgrensning).

- Afklaring om behovet for ECA områder, herunder tekniske og økonomiske konsekvenser på både $\mathrm{SO}_{\mathrm{x}}$ og $\mathrm{NO}_{\mathrm{x}}$ (Tier III).

- Afklaring af omfanget for flagsstatskontrol og havnestatskontrol.

- Udarbejdelse af et notat om økonomiske konsekvenser. 


\subsection{Projektforslag}

Et projekt for opfølgning kan være et eller flere af følgende forslag.

Studie

Anslåede omkostninger (1000 DKK)

Implementering af kontrol af af $\mathrm{SO}_{\mathrm{x}}, \mathrm{NO}_{\mathrm{x}}$ og ODS 250

(flag- og havnestatsansvar, beslutningsstøtte, praktiske fremgangsmåder)

Workshop med skabeloner og værktøjer til 250 implementering af $\mathrm{SO}_{\mathrm{x}}, \mathrm{NO}_{\mathrm{x}}$ og ODS regulering

Studie af behov for modtageanlæg og bræendstofkontrol 250 som en tværgående indsats på alle dele af MARPOL Annex VI (reglerne 12-18) 


\section{Referencer}

IMO (2013) MARPOL - How to do it: Manual on the practical implications of ratifying and implementing MARPOL 73/ 78

(http:/ / www.imo.org/ en/ Publications/ Documents/ Newsletters\%20and\%20Mailers/ Mailers/ I B636E.pdf)

IMO (2013) MARPOL annex VI and NTC 2008 with guidelines for implementation.

(http:/ / www.imo.org/ en/ Publications/ Documents/ Newsletters\%20and\%20Mailers/ Mailers/ I B664E.pdf)

IMO (2015) MARPOL Consolidated Edition 2011 - International Convention for the Prevention of Pollution from Ships. Supplement September 2015.

Solofa (2009) Ocean Governance In Samoa: A Case Study Of Ocean Governance In The South Pacific. Division For Ocean Affairs And The Law Of The Sea Office Of Legal Affairs, The United Nations, NewYork, 2009

Søfartsstyrelsen, marts 2017, Kvælstofoxid $\left(\mathrm{NO}_{\mathrm{x}}\right)$, http:// www.soefartsstyrelsen.dk/Vaekst/MiljoeKlima/KvaelstofOxid

EMSA (2017) https:// portal.emsa.europa.eu/ widget/web/thetis/ ship-risk-profile-calc/LShipRiskProfile_WAR_portletpublic 


\section{Bilag: Tabel over lovgivning}

Se Bilag 1 


\section{Bilag 1}

Oversigt over den nuværende status af implementering af MARPOL Annex VI i Danmark, Grønland, Island og Færøerne

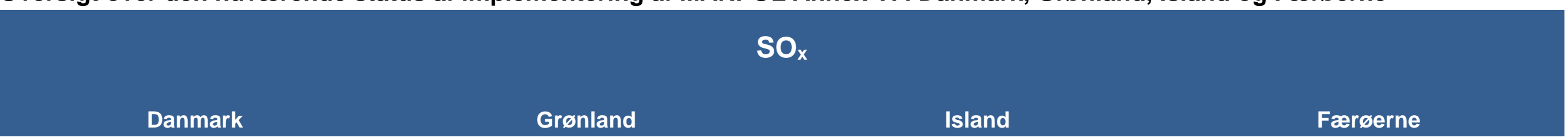

Reduktion af $\mathrm{SO}_{x}$ udledning via begrænsning af svovlindhold i brændstof. Global: 3,5 \% efter 2012 og 0,5\% efter 2020,

ECA/SECA-område: 0,1 \% efter 2015 (MARPOL Annex VI - Regulation 14)

Bekendtg $\varnothing$ relse $^{A}$ Kapitel 3, §7-14 Dette kapitel fastsætter regler om krav til brændstof, herunder hvilken brændstof må markedsføres, forpligtelser ved modtagelse af brændstof og anvendelsen af skibsbrændstoffer
Ingen regler. Men $\S 25$. Landsstyret kan til beskyttelse af det grønlandske søterritorium fastsætte regler om særlige foranstaltninger, herunder krav til brændstof, om bord på skibe med henblik på begrænsning af luftforurening.
På grund af E $\varnothing \mathrm{S}$-aftalen har Island implementeret direktiv 2012/33/EU i den nationale lovgivning med Forordning nr. 124/2015 om svovlindhold i visse flydende brændstoffer. Forordningen fastsættes i henhold til loven om kemikalier, $\mathrm{nr}$. 61/2013. Derfor har Island fastsæt de bestemmelser om svovlindhold $i$ skibsbrændstoffer som findes i MARPOL Annex VI.

Alternativ: rense udst $\varnothing$ dningsgassen med Exhaust Gas Cleaning System - scrubber (MARPOL ANNEX VI - Regulation 4.1)

\section{Bekendtg $\varnothing$ relse ${ }^{A}$}

Kapitel 3, §17

regulerer anvendelse af

emissionsreduktionsmetoder og

henviser til bilag 2 og 3 for særlige krav
Ingen regler

Identiske bestemmelser og findes $\mathrm{i}$

direktiv 2012/33/EU.
Ingen regler om krav til brændstof, men ministeren har hjemmel til at fastsætte regler om bl.a. indhold af svovl $\mathrm{i}$ brændstof.
Ingen regler 
so $_{x}$

Udledning af vaskevand fra røgvaskere til havet (IMO MEPC.184(59))

\section{Bekendtg $\varnothing$ relse ${ }^{A}$}

\section{Bilag 2}

I denne bilag står reglerne hvornår vaskevand må udledes i havet. yderligere gælder vilkår fra scrubbers typegodkendelse
Afhængig af hvordan det udledes kan det være omfattet: § 17. På grønlandsk søterritorium må udtømning af affald, bortset fra frisk fisk og dele heraf, ikke finde sted
Ingen særlige regler vedrørende vaskevand fra røgvaskere til havet, men ifølge lov nr. 33/2004 er udledninger i havet fra skibe generelt forbudt, medmindre andet udtrykkeligt er anført.
I §20 i havmiljøloven om anden forurening står, at ministeren kan, herunder til opfyldelse af internationale aftaler og lovens formål, fastsætte regler om at forebygge eller mindske forurening og anden påvirkning af natur og miljø fra virksomhed på havet, som ikke er nævnt i §§2-11.

\section{Kontrol/håndhævelse}

\section{Bekendtg $\varnothing$ relse ${ }^{A}$}

Kapitel 5

Miljøstyrelsen, Søfartsstyrelsen og Kommunalbestyrelsen er ansvarlig for tilsyn
$\S 36$. Landsstyret kan udstede regler om kontrollen med overholdelse af bestemmelser i landstingsforordningen og regler udstedt i medfør heraf.

Stk. 2. Forsvarets Fiskeriinspektion og politiet påser overholdelse af bestemmelserne $\mathrm{i}$

landstingsforordningen og i regler efter landstingsforordningen.
Miljøstyrelsen og Icelandic Transport Authority er ansvarlig for tilsyn.

Kontrol/håndhævelse har hjemmel $\mathrm{i}$ loven om kemikalier og forordning $\mathrm{nr}$. $124 / 2015$.
Kontrol har hjemmel i §34 og kan deles mellem miljøstyrelsen, og kontrollen kan uddelegeres til andre myndigheder, p.t. søfartsstyrelsen og fiskeriinspektionen (både dansk og færøsk)

Modtagefaciliteter Modtagelse af rester fra rensning af udstødningsgas 


\section{so $_{x}$}

Danmark

\section{Bekendtgørelse ${ }^{\mathrm{A}}$}

\section{Kapitel 4}

Havnebestyrelse eller den for havne ansvarlige etableres en ordning til modtagelse
Grønland

Ingen regler, har en fors $\varnothing$ gsordningen men...

$\S 18$. Landsstyret fastsætter regler og træffer bestemmelse om oprettelse og indretning af anlæg til modtagelse af rester af olie og skadelige flydende stoffer samt affald i havne. Det kan herunder bestemmes, at det pålægges bunkringsvirksomheder, virksom heder, som foretager afskibning eller modtagelse af olie, virksomheder, som foretager afskibning eller modtagelse af skadelige flydende stoffer, samt skibs reparationsvirksomheder at etablere modtageanlæg for olie og kemikalieblandet ballast og tankskyllevand.
Island

Ingen særlige regler, men

havnebestyrelser er ansvarlig for at der i havne stilles modtagefaciliteter som er tilstrækkelige til at imødekomme behovene for de skibe, der normalt anløber havnene, jf Lov nr. 33/2004 og Forordning nr. 1200/2014 om modtagelse af driftsaffald og lastrester fra skibe (implementering af direktiv 2000/59/EU).

\section{Reference}

\section{A: Svovlbekendtgørelsen -}

Bekendtgørelse om svovlindholdet i faste og flydende brændstoffer (https://www.retsinformation.dk/forms /R0710.aspx?id=163364)

B: Bekendtgørelse om Meddelelser fra Søfartsstyrelsen B, skibes bygning og

\section{Landstingsforordning nr. 4 af 3.}

november 1994 om beskyttelse af havmiljøet
Lov om kemikalier/efnalög nr. 61/2013: http://www.althingi.is/lagas/nuna/2013 061.html

Forordning/reglugerð nr. 124/2015.

http://www.reglugerd.is/reglugerdir/all $\mathrm{ar} / \mathrm{nr} / 124-2015$

\section{Farøerne}

Havmiljøloven §16:

Miljøministeren kan fastsætte regler og træffe bestemmelse om oprettelse og indretning af anlæg til modtagelse af rester af olie, skadelige flydende stoffer, ozonlagsnedbrydende stoffer og udstyr, der indeholder ozonlagsnedbrydende stoffer, kloakspildevand samt affald $i$ havne,

Processpildevand er ikke nævnt, så her må nok en lovændring til. 
so $_{x}$

Danmark

udstyr i skibe m.v.

(https://www.retsinformation.dk/forms

/R0710. aspx?id=185405)
Grønland

Island

Færøerne

Lov/lög nr. 33/2004:

http://www.althingi.is/lagas/nuna/2004

033.html

Forordning/reglugerð nr. 1200/2014:

http://www.reglugerd.is/reglugerdir/all

$\mathrm{ar} / \mathrm{nr} / 1200-2014$ 


\section{NOx}

$\mathrm{NO}_{\mathrm{x}}$ udledning ifølge Tier II standard; $\mathrm{NO}_{\mathrm{x}}$ udledning i ECA-områder

skal reduceres med ca. 75\% ifølge Tier III standard (MARPOL ANNEX VI - Regulation 13)

\section{Bekendtg $\varnothing$ relse ${ }^{\mathrm{B}}$}

Kapitel XXVI, Regel 13, 1-5

Søfartsstyrelsen er ansvarlig for

reglerne om de tekniske installationer

om bord i skibene
Ingen regler Ingen regler

Den færøske søfartsstyrelse er ansvarlig for reglerne angående de tekniske installationer om bord i færøske skibe i mht. færøsk lov om sikkerhed til søs

\section{Kontrol/håndhævelse}

\section{Bekendtgørelse ${ }^{\mathrm{B}}$}

\section{Kapitel XXVI, Regel 13}

Certificerings-, afprøvnings- og måleprocedurerne for de relevante standarder nævnes i NO koden af 2008

Ingen regler Ingen regler

$\S 36$. Landsstyret kan udstede regler om

kontrollen med overholdelse af

bestemmelser i landstings-forordningen

og regler udstedt i medf $\varnothing$ r heraf.

Stk. 2. Forsvarets Fiskeriinspektion og

politiet påser overholdelse af

bestemmelserne i landstings-

forordningen og i regler efter

landstingsforordningen

ngen regler
Løgtingslóg nr 1652001 um trygd á

sjónum, §§17-21

Kunngerđ frá 1. mai 2016 frá

Sjóvinnustýrinum um byggi- og

útgerđarkrøv o.a., som er en

bekendtg $\varnothing$ relse fra den færøske

søfartsstyrelse af Bekendtg $\varnothing$ relse om

Meddelelser fra Søfartsstyrelsen B,

skibes bygning og udstyr i skibe m.v. 


\section{NOx}

Reference

\section{B: Bekendtgørelse om Meddelelser fra} Søfartsstyrelsen B, skibes bygning og udstyr i skibe m.v.

(https://www.retsinformation.dk/forms

/R0710.aspx?id=185405)

\section{Landstingsforordning nr. 4 af 3.}

november 1994 om beskyttelse af

havmiljøet
Løgtingslóg nr 1652001 um trygd á

sjónum, §§17-21

Kunngerð frá 1. mai 2016 frá

Sjóvinnustýrinum um byggi- og

útgerđarkrøv o.a., som er en

bekendtgørelse fra den færøske

søfartsstyrelse af Bekendtg $\varnothing$ relse om

Meddelelser fra Søfartsstyrelsen B,

skibes bygning og udstyr i skibe m.v. 


\section{ODS}

Forbud forsætlige emissioner af ozonlagsnedbrydende stoffer, som omfatter haloner og chlorfluorcarboner (MARPOL Annex VI - Regulation 12)

\section{Lov om kemikalier}

Bekendtgørelse om visse

ozonlagsnedbrydende stoffer og

Bekendtg $\varnothing$ relse ${ }^{\mathrm{C}}$

$\S 3$

Miljøstyrelsen regulerer forbud og undtagelse
Umiddelbart Ingen regler

Lov om kemikalier nr. 61/2013.

Forordning nr. 970/2013, om

ozonlagsnedbrydende stoffer, som

implementerer bestemmelser fra

forordning (EF) nr. 1005/2009.
Ikke specifik lov om kemikalier. men eget

kapitel i miljøloven, kapitel 5a:

Begrænsninger i import, eksport, forbrug

o.a. af kemikalier.

Installationer taget i brug efter den 19. maj 2005 må ikke indeholde ozonlagsnedbrydende stoffer undtagelse: hydrochlorofluorocarbon (HCFC) frem til Januar 2020

\section{Bekendtgørelse ${ }^{\mathrm{C}}$}

$\S 4$

Miljøstyrelsen regulerer forbud og undtagelse
Ingen regler

Installation af nye køleanlæg som

indeholder ozonnedbrydende stoffer,

inkluderet HCFCer, har været forbudt

fra 1997 i det mindste.

Umhverfisstofnun regulerer forbud og

undtagelse.
Bekendtgørelse om ozonlagnedbrydende

stoffer.

Generelt forbud, $\S 4$

CFC udfases i 2011, § 6

HCFC udfases i 2016, § 6 


\section{ODS}

Kontrol/overvågning

\section{Bekendtgørelse ${ }^{\mathrm{C}}$}

§, §9

Miljøstyrelsen fører tilsyn med overholdelse af reglerne, straffen er bøde eller kan stige til fængsle
$\S 36$. Landsstyret kan udstede regler om kontrollen med overholdelse af bestemmelser $\mathrm{i}$

landstingsforordningen og regler udstedt i medfør heraf.

Stk. 2. Forsvarets Fiskeriinspektion og politiet påser overholdelse af

bestemmelserne i

landstingsforordningen og i regler efter landstingsforordningen.

\section{Umhverfisstofnun fører tilsyn med} overholdelse af regler om ozonnedbrydende stoffer generelt. Samgöngustofa (The Icelandic Transport Authority) har tilsyn med overholdelse af reglerne i skibe.

Straffen er bøde, der kan stige til fængsel.
Bekendtgørelse om ozonlagnedbrydende stoffer fra 2010, § 14.

Den færøeske Miljøstyrelse fører tilsyn med overholdelse af reglerne, straffen er bøde, der kan stige til fængsling 


\section{ODS}

Modtagefaciliteter/modtagelse af ozonlagsnedbrydende stoffer

\section{Bekendtg $\varnothing$ relse ${ }^{c}$}

$\S 7$ Modtageanlæg I havne

Bekendtg $\varnothing$ relse ${ }^{\mathrm{B}}$

Kapitel XXVI, Regel 17

Havnebestyrelse eller den for havne ansvarlige etableres en ordning til

modtagelse
Ingen regler men...

$\S 18$. Landsstyret fastsætter regler og

træffer bestemmelse om oprettelse og

indretning af anlæg til modtagelse af

rester af olie og skadelige flydende

stoffer samt affald i havne. Det kan

herunder bestemmes, at det pålægges

bunkringsvirksomheder, virksom

heder, som foretager afskibning eller

modtagelse af olie, virksomheder, som

foretager afskibning eller modtagelse

af skadelige flydende stoffer, samt

skibs reparationsvirksomheder at

etablere modtageanlæg for olie og

kemikalieblandet ballast og

tankskyllevand.

\section{Forordning nr. 970/2013.}

Alle brugte kølemidler skal indsendes

for destruktion. Der findes dog ikke

særlige modtageanlæg i havne.
Producent/import ansvar, §9, stk. 3,

godkendte modtagere

\section{Referencer}

C: Bekendtgørelse om forebyggelse af luftforurening fra skibe og platform (https://www.retsinformation.dk/eli/lt a/2015/1542)
Landstingsforordning nr. 4 af 3. november 1994 om beskyttelse af havmiljøet
Forordning nr. 970/2013

(http://www.reglugerd.is/reglugerdir/

eftir-

raduneytum/umhverfisraduneyti/nr/1 8841)
Miljøloven: Løgtingslóg nr. 1341988 um umhvørvisverend (mere eller mindre den samme som den danske miljølov fra midten af 1980-erne) 


\section{ODS}

Island

Farøerne

Lov om kemikalier nr. 61/2013

(http://www.althingi.is/lagas/nuna/20

13061.html

2010 um ozonoyđandi evni 


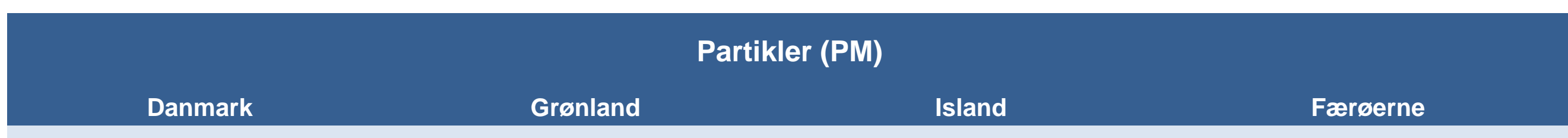

Partikelemission er knyttet til svovl i brændstoffet, som danner sulfat partikler. Af denne grund er der ingen specifikke emissionsgrænse-værdier for partikler.

\section{Ingen regler men..}

Lov om miljøbeskyttelse

Bekendtg $\varnothing$ relse om vurdering og

styring af luftkvaliteten

$\rightarrow$ Gælder i havn
Ingen regler

Ingen særlige regler vedrørende

skibsbrændstoffer.
Ingen regler 


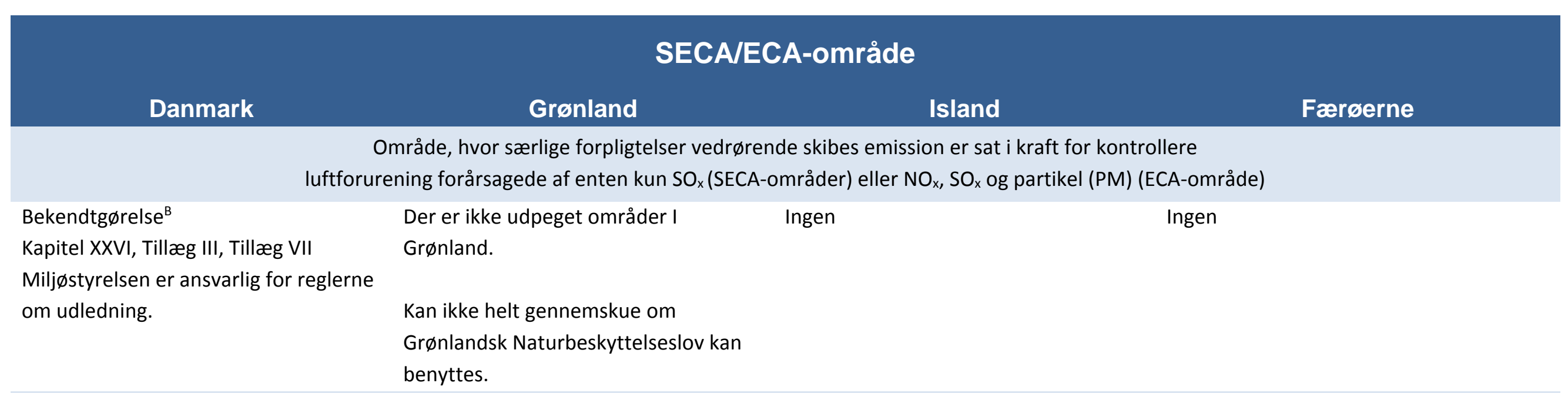

\section{Reference}

B: Bekendtgørelse om Meddelelser fra Søfartsstyrelsen B, skibes bygning og udstyr i skibe m.v.

(https://www.retsinformation.dk/form s/R0710.aspx?id=185405) 


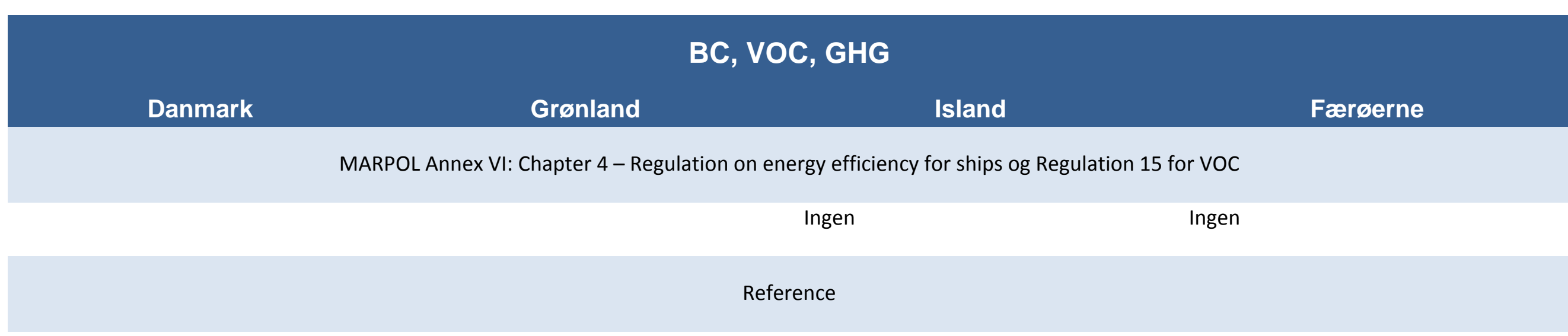




\section{Forkortelser}

ECA

SECA

ODS

BC

VOC

GHG
Emissionskontrolområde

Svovl emissionskontrolområde

Ozonnedbrydende stoffer

Black carbon

Volatile organic compounds

Greenhouse gases 